\title{
滲出性中耳炎に招ける急性中耳炎の関与
}

\author{
小林 一豊・山岸みどり・児玉 広幸 \\ 竹沢 裕之・鈴木 敏夫・形浦 昭克
}

\section{Infants with Otitis Media with Effusion, with and without Acute Otitis Media}

\author{
Kazutoyo Kobayashi, Midori Yamagishi, Hiroyuki Kodama, \\ Hiroyuki Takezawa, Toshio Suzuki and Akikatsu Kataura \\ (Sapporo Medical College)
}

Acute otitis media (AOM) is one of the most common infectious disease in childhood. The purpose of this study was to clarify the association between AOM and otitis media with effusion (OME). A nine-year retrospective study was conducted of 131 children with OME (219 ears).

The patients were classified into four groups according to the clinical course of hearing impairment.

The incidence of AOM in OME patients was $65.6 \%$ on the average, and a history of AOM was a significant risk factor for the development of chronic OME.

The diagnosis of AOM is difficult in young infants. Our results suggest that AOM in early infancy is a strong predictor of recurrent middle ear problems later in childhood.

In order to prevent this, AOM in young infants must be treated as effectively as possible. This therapy includes proper antimicrobial treatment, myringotomy, drainage of the middle ear and careful follow up.

Key words: otitis media with effusion, acute otitis media, retrospective study

\section{研究目的}

小児の渗出性中耳炎には，様々の発症因子が 関与していると考兄れて括り，特に，急性中 耳炎がその発症の引金として大きく関わってい ると推測されている.

現在まで種々の疫学的な検討が行われている が1)2), 今回, 我々は滲出性中耳炎之急性中耳 炎との関連性についてアンケート調査を行い更 に検討したので報告する.
対象と方法

対象は札幌医科大学滲出性中耳炎外来で診断, 治療, 経過観察を行った小児渗出性中耳炎131 症例 (男91例, 女40例), 一側43耳, 両側 176 耳 の計219耳である. 初診時年齢は $3 \sim 14$ 歳であ る. 検査としては, ティンパノグラム, 純音聴 力検査を行い, 治療は主に鼓膜切開, 換気チュー ブ留置術を施行している.

これらの症例にたいして表 1 の如くアンケー 卜調査を行い, 急性中耳炎の既往と滲出性中耳 
炎との関連性について臨床的検討を挆こなった。 アンケート調査結果から難聴を指摘または自覚 した年齢によって 4 群にわけ, 各々の群での急 性中耳炎の初発年齢, 頻度などを比較した。併 せて, 鼓膜切開, 換気チューブ留置術などの治 療をらけた頻度についても検討した。

\section{結果}

今回のアンケート調査で難聴を指摘された年 齢(聞こえが良くないのに保護者が気がついた 年齢) と渗出性中耳炎と診断された年齢とを比 較すると, 表 2 の如く大部分の症例が難聴を指
摘されてから 1 年以内に滲出性中耳炎と診断さ れて扣り，このアンタート項目での難聴指摘年 齢が滲出性中耳炎発生時期と近似していると推 測された.

またアンケート回収年齢の平均は14.9歳であ り，難聴を指摘された年齢が 9 歳以上の群でア ンケート回収時の年齢もやや高い傾向がみられ た(表 3 ).

難聴指摘年齢から平均 8.89 年後にアンケート を回収して扣り，この時点で注注全例が治癒し ていた.

表 1 渗出性中耳炎アンケート項目

\section{渗出性中耳炎質問表}

名前 ）性別（男，女）

生年月日 昭和 年 月生 歳

1）聞こえが良くないのに気が付いたのは何歳の ときですか。

2) 水が貯っていると言われたのはどちらの耳で すか。

(右, 左, 両耳)

3 ) 水が貯っていると言われたのは何歳の時です か. (生後歳)

4) どこの病院で水が貯っていると言われました か.

5 ）鼓膜切開をして水を抜いたことがありますか， （ある，ない）

6）もし水を抜いたことがあれば，その頻度はど れくらいですか。

右耳：1 カ月に 1 回以上, $2 \sim 3$ 力月に 1 回, $4 \sim 6$ カ月に 1 回, 1 年に 1 回以下) 左耳：1 カ月に 1 回以上, $2 \sim 3$ カ月に 1 回, $4 \sim 6$ 力月に 1 回, 1 年に 1 回以下)

7 ) 最初に鼓膜切開をしたのは何歳の頃ですか.

8 ）最後に鼓膜切開をしたのは何歳の頃ですか.

9 ）鼓膜にチューブをいれたことがありますか.

$$
\text { (ある,ない) }
$$

10）チューブをいれた方に質問します.チューブ は何回いれをしたか。

（右耳回）（左耳

回）
11）1つのチューブは平均どのくらいの期間入っ ていましたか。

( 1 力月以内, $2 \sim 3$ 力月, $4 \sim 6$ 力月, $6 \sim 12$ 力月, 1 年以上)

12）最初にチューブをいれたのは何歳の頃ですか.

13）最後にチューブをいれたのは何歳の頃ですか 歳ですか。

15）渗出性中耳炎の治療を終了した年齢は何歳で すか。

16）滲出性中耳炎の治療を受けた期間はどれくら いですか.（年力月）

17）水が貯らなくなったのは何歳ごろですか.

18）水が貯る前に，同じ側の耳急性中耳炎を括 こしたことがありますか。

（ある，ない，不明）

19）もしあ机ば，初めて起こした年齢は何歳です か. (生後歳)

20）また， 1 年に何回くらい急性中耳炎をおこし ましたか。

21）急性中耳炎はどの位でな和りましたか. ( 2 週間以内, $2 \sim 4$ 週間, $1 \sim 2$ 力月, $2 \sim 3$ 力月, 3 力月以上)

22）急性中耳炎を起こさなくなったのは，何歳頃 ですか。

(生後 歳)

23）現在, 次のような症状は残っていますか. (難聴, 耳だれ, 鼓膜穿孔, その他く 特にない) 
難聴を指摘された年齢と急性中耳炎の初発年 齢とを比較すると表 4 の如く, 難聴を指摘され た年歯が低い群棌ど，急性中耳炎の初発年齢も 低い傾向が認められ，併せて急性中耳炎に高い 頻度で罹患する傾向がみられた（図 1)。しかし， $3 \sim 4$ 歳群では $5 \sim 6$ 歳群に比較してむしろ急 性中耳炎の罹患頻度は減少する傾向がみられた。 滲出性中耳炎は, 急性上気道炎の罹患後に少し 遅れて発症するとの報告がみられるが，今回検 討した結果も急性中耳炎の既往と滲出性中耳炎 の発症に密接な関係があることを示唆する結果 であった3).

急性中耳炎が滲出性中耳炎に先行する頻度は

表 2 滲出性中耳炎診断年齢

\begin{tabular}{|c|c|c|}
\hline $\begin{array}{l}\text { 難聴指摘 } \\
\text { 年歯令(歳) }\end{array}$ & 症例数 & 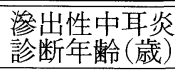 \\
\hline $3 \sim 4$ & 40 & $4.80 \pm 0.25$ \\
\hline $5 \sim 6$ & 57 & $5.27 \pm 0.08$ \\
\hline $7 \sim 8$ & 18 & $7.94 \pm 0.47$ \\
\hline $9 \sim$ & 16 & $10.53 \pm 0.38$ \\
\hline 計 & 131 & \\
\hline
\end{tabular}

(平均士標準誤差)

表 3 アンケート回収年齢

\begin{tabular}{c|c}
\hline \hline 難聴指摘年齢（歳） & アンケート回収年龄（歳） \\
\hline $3 \sim 4$ & $14.2 \pm 0.35$ \\
$5 \sim 6$ & $14.6 \pm 0.25$ \\
$7 \sim 8$ & $15.7 \pm 0.40$ \\
$9 \sim$ & $17.9 \pm 0.65$
\end{tabular}

(平均値士標準誤差)

表 4 急性中耳炎初発年齢

\begin{tabular}{c|c}
\hline \hline 難聴指摘年齢（歳） & 急性中耳炎初発年歯（歳） \\
\hline 3 4 & $2.59 \pm 0.23$ \\
$5 \sim 6$ & $3.64 \pm 0.27$ \\
$7 \sim 8$ & $4.92 \pm 0.40$ \\
$9 \sim$ & $5.17 \pm 0.71$
\end{tabular}

(平均值士標準誤差)
各年齢群で同様の傾向を示し，平均65.6\%であ った。

また，従来の報告通り低年齢群ほど両側滲出 性中耳炎が多く，年齢が高くなる匡ど一側性沴 出性中耳炎の占める割合が高くなる傾向がみら れた(表 5 )。

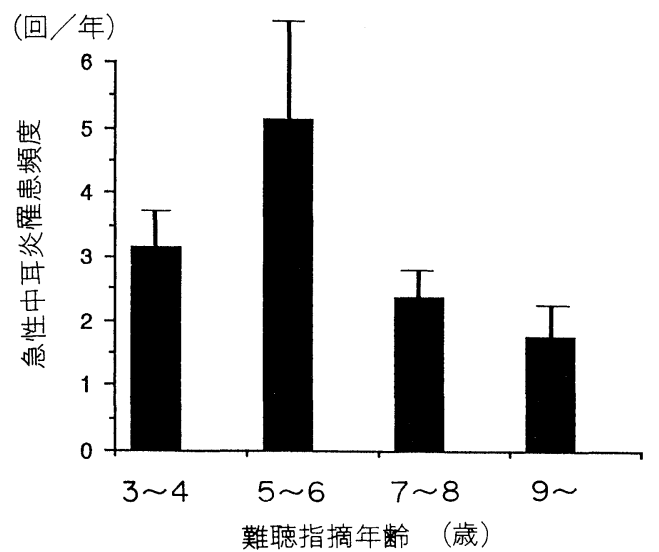

図 1 急性中耳炎罹患頻度 (平均値士標準誤差)

表 5 滲出性中耳炎罹患側

\begin{tabular}{|c|c|c|c|}
\hline \multirow{2}{*}{$\begin{array}{l}\text { 難聴指摘 } \\
\text { 年歯令 (歳) }\end{array}$} & \multirow{2}{*}{ 症例数 } & \multicolumn{2}{|c|}{ 例数 $(\%)$} \\
\hline & & 両側性 & 一側性 \\
\hline $3 \sim 4$ & 40 & $31(77.5 \%)$ & $9(22.5 \%)$ \\
\hline $5 \sim 6$ & 57 & $40(70.2 \%)$ & $17(29.8 \%)$ \\
\hline $7 \sim 8$ & 18 & $10(55.6 \%)$ & $8(44.4 \%)$ \\
\hline $9 \sim$ & 16 & $7(43.8 \%)$ & $9(56.2 \%)$ \\
\hline
\end{tabular}

表 6 鼓膜切開, 鼓室チューブ留置術の適応基準

鼓膜切開の適応

1) 保存的治療を 3 力月間以上行っても, 貯留 液をみとめるもの.

2）日常生活に支障のある $30 \mathrm{~dB}$ 以上の聴力低 下が存在すること.

3 ) 滲出性中耳炎の急性増悪. 鼓室内チューブ留置術の適応

1 ) 鼓膜切開を行っても，3 力月以内に滲出性 中耳炎の再発を生じる症例.

2) Atelectatic ear drum, blue ear drum 等の 症例. 
表 7 滲出性中耳炎の治療回数

\begin{tabular}{|c|c|c|}
\hline \multirow{2}{*}{$\begin{array}{l}\text { 難聴指摘 } \\
\text { 年鈴 (歳) }\end{array}$} & \multicolumn{2}{|c|}{ (回数／耳／年) } \\
\hline & $\begin{array}{l}\text { 鼓室チューブ } \\
\text { 留 }\end{array}$ & 鼓膜切開 \\
\hline $3 \sim 4$ & $0.34 \pm 0.05$ & $1.11 \pm 0.13$ \\
\hline $5 \sim 6$ & $0.40 \pm 0.04$ & $0.91 \pm 0.08$ \\
\hline $7 \sim 8$ & $0.40 \pm 0.11$ & $0.98 \pm 0.30$ \\
\hline $9 \sim$ & $0.23 \pm 0.07$ & $0.70 \pm 0.11$ \\
\hline
\end{tabular}

(平均値士標準誤差)

また，当科渗出性中耳炎外来で表 6 の基準に 従って治療を持こなった。その結果, 難聴指摘 年齢が低い群注ど鼓膜切開を行ら回数が高い傾 向がみられた。また鼓室チューブ留置の頻度は 各年齢群で有意な差を認めなかった（表 7 ）。

\section{考察}

Sade は滲出性中耳炎患者の $65 \%$, Kokko は $78 \%$ に急性中耳炎の既往があったと述べ，Van Cauwenberg らやKraemer らも急性中耳炎が 滲出性中耳炎のリスクファクターになっている と指摘している4) 7).

本邦でも，急性中耳炎患者の $10 \%$ は滲出性中 耳炎に移行すると報告されている3.

また，急性中耳炎罹患時の鼓膜発赤の程度が 強く, 発赤消失時の TG (tympanogram) が C 2 またはB型を示す症例では $20 \%$ が滲出性中耳 炎になると報告されている318)。これらの報告は 急性中耳炎の炎症の程度や既往と滲出性中耳炎 発症との間に密接な関係があることを示唆して いる.

急性中耳炎との関連については，漻出性中耳 炎症例の中には，急性中耳炎の症状(発熱, 耳 痛, 鼓膜発赤)に引き続いて長期間中耳腔に貯 留液が認められる例と急性中耳炎が一度消退し てから貯留液を生ずる例の 2 種類の病態がある と報告されている2)8).

金子らは学童の集団検診で発見される渗出性 中耳炎の大部分は急性中耳炎との連続性がなく, 過去に急性中耳炎の既往のあったものが有意に 多いと報告している2).
急性中耳炎の年齢分布は生後 6 力月から11力 月の間で最も多く発症するとの報告や $4 \sim 5$ 歳 にピークがあるとする等の報告があるが，一般 に 6 歳をすぎると減少する傾向を示し，8歳以 上で激減する910).

竹内らは 1 歳未満の年齢の小児では急性中耳 炎に罹患しても耳痛を訴兄ず，同時にみられる 発熱, 感冒症状から小児科等で治療をらけるこ とが多いため， みかけ上急性中耳炎の罹患頻度 が少なくなると述べている11).

我々の結果でも $3 \sim 4$ 歳の年齢層で急性中耳 炎の罹患頻度が少なくなってきて抢り，低年齢 の小児では急性中耳炎に気づきにくいことを反 映しているものと考穴られた。

$6 \sim 8$ 歳以上で急性中耳炎の発症が少なくな る原因は，耳管や上咽頭の解剖学的变化拉よび 中耳, 全身の免疫機能の発達, 成熟が関与して いると考兄られている.上咽頭の形態は 6 歳で 急速に広くなり，この解剖学的变化も急性中耳 炎に罹患しづらくなる一因と思われた。市た， 扁桃，アデノイド組織等の免疫担当細胞の加齢 による変化については，加齢と共にBリンパ球 が減少していくことが報告されており，加齢に 伴う上気道の免疫機能の変化を反映していると 考觉られる12).

急性中耳炎の病因は細菌やウイルスなどによ る中耳感染であるが，急性炎症が消退しても中 耳腔に菌体抗原やエンドトキシンが残った場合， III型アレルギー等を生じて炎症の遷延化を招き， 最終的に滲出性中耳炎に移行すると推測されて いる. 山中らは渗出性中耳炎患者の中耳貯留液 には IgG, IgM おょび IgA immune complex が存在し, 補体の活性化により, 中耳炎の遷延 化に関与していると述べている13).

上咽頭, 中耳貯留液の細菌学的検索でも滲出 性中耳炎の発症に急性中耳炎が関与していると の考劣を示唆する報告がみられる．即ち急性中 耳炎扣よび渗出性中耳炎の貯留液や上咽頭の細 菌培養検查は洰淁一致し, S. pneumoniae, H. influenzae が多く検出されると報告されてい 
$3^{14)}$.この中で滲出性中耳炎の中耳貯留液の細 菌培養検查では193例258耳の30\%から菌が検出 され，この中で分離された病原菌としては $\mathrm{H}$. influenzae が最も多いと報告されている. 浅野 は急性化膿性中耳炎は最近の抗生物質の進歩に 伴ってインフルェンザ菌が原因菌となることが 多く，臨床症状が目だたないため見逃される ケースが非常に多くなってきており, この症状 変貌が最近の滲出性中耳炎の増加の一因と述べ ている15)。併せて, 飯野らは貯留液中のエンド トキシンを測定し，エンドトキシン濃度が高い 症例法ど遷延化する傾向があると述べている16).

以上から, 現在滲出性中耳炎の発症要因とし て急性中耳炎の炎症産物が中耳腔に括いて適切 な処理をらけないで残留し, 中耳粘膜の治瘉機 転が障害されたため生じることが一因と推測さ れて扔り, 従来からの実験的渗出性中耳炎の結 果もこの考皇裏づけいる.

また，今回の検討で急性中耳炎の初発年齢が 低い程, 滲出性中耳炎発症年齢も低い傾向がみ られた．急性中耳炎の治癒に要する日数は，2 歳以下では他の年齢に比し遷延化すると報告さ れている.これは個体の免疫学的成熟が完全で はないことも一因と思われる。このため低年齢 層の小坚では, より滲出性中耳炎に移行しやす いことが予想される．以上述べたごとく，急性 中耳炎は滲出性中耳炎の発症に強く関与してい ることが示唆された。

この急性中耳炎は滲出性中耳炎と同様に低年 齢層では両側性が多く, 年長児になるに従って 一側性が多くなると報告されている11). 今回我 我の検索した症例でも加齢と共に一側の滲出性 中耳炎が多くなる傾向がみられた.

今回の結果から低年齢時に発症した急性中耳 炎は高率に滲出性中耳炎に移行することが予想 される. それ故，幼小児の急性中耳炎に対して は迅速に適切な抗生物質の投与や鼓膜切開によ る中耳腔 drainage を行い, 急性炎症が消退し た後も定期的に follow up することが滲出性中 耳炎への移行を予防する上で重要と思わ机た。

\section{結 語}

小児滲出性中耳炎131症例(219耳) そアンケー 卜調査を行い以下の結果を得た。

1）難聴を指摘された年齢が低い群流ど，急 性中耳炎の初発年齢が低く，急性中耳炎飞高い 頻度で罹患する傾向がみられた。

2 ）急性中耳炎が參出性中耳炎に先行する頻 度は, 平均 $65.6 \%$ であった。

3 ) 低年齢群㟫ど両側の滲出性中耳炎が多く, 年齢が高くなるに従い，一側性の渗出性中耳炎 の割合が高くなる傾向がみられた.

以上から, 急性中耳炎は渗出性中耳炎の重要 なリスクファクターであると考兄られ，急性中 耳炎の適切な治療が滲出性中耳炎への移行を予 防する上で必須と思われた。

本研究の要旨は平成元年10月27 28日 (東京)の第 17回日本臨床耳科学会に扮いて報告した.

\section{文献}

1) Virolainen E, Puhakka H, Aantaa E, et al : Prevalence of secretory otitis media in seven to eight year old school children. Ann Otol Rhinol Laryngol 89 Suppl $68: 7 \sim 10,1980$.

2) 金子 豊, 沖津卓二, 高坂知節, 他 : 急性中耳 炎の既往と滲出性中耳炎. 耳喉 $57:$ 901 905, 1985.

3）中嶋慶則, 服部康夫 : 小児急性中耳炎の臨床的 観察. 日耳鼻 $92: 347 \sim 352,1989$.

4) Sade $J$ : Inflammatory and non-inflammatory factors related to secretory otitis media. Int $\mathrm{J}$ Pediatr Otolaryngol 1: 41 59, 1979.

5) Kokko E : Chronic secretory otitis media in children; a clinical study. Acta Otolaryngol Suppl 327 : 1 44, 1974.

6) Van Cauwenberg PB and Kluyskens PM : Some predisposing factors in otitis media with effusion. Recent Advances in OME (ed by Lim DJ, et al). pp $28 \sim 32$, BC Decker Inc, Philadelphia, Toronto, 1984.

7) Kraemer MJ, Richardson MA, Weiss NS, et al : Risk factors for persistent middle-ear effusions. JAMA $249:$ 1022 1025, 1983. 
8）芦川英通，山根 位：0 歳急性中耳炎の統計的 観察.耳鼻臨床 $80 ： 1827 \sim 1832,1987$.

9) Howie VM, Ploussard JH and Sloyer J : The "otitis-prone" condition. Am J Dis Child 129 : $676 \sim 678,1975$.

10）南 吉昇：小児急性中耳炎の統計的観察. 耳喉 $56: 115 \sim 119,1984$.

11）竹内万彦, 間島雄一, 浜口幸吉, 他 : 小児渗出 性中耳炎の予後を左右する因子.耳鼻臨床 82 ： 921 924, 1989.

12）松山秀明, 山中 昇: 小児口蓋扁桃掞よび咽頭 扁桃に打忷る免疫組織学的研究一画像解析に上 る定量的検索一. 日耳鼻 $92 ： 2064 \sim 2078,1989$.

13) Yamanaka N, Somekawa $Y$ and Kataura A : Immunologic and cytologic studies in otitis media with effusion. Acta Otolaryngol
(Stockh) $104:$ 481 486, 1987.

14) Freijid A, Bygdeman $S$ and Rynnel-Dagoo B : The nasopharyngeal microflora of otitis-prone children, with emphasis on $\mathrm{H}$. influenzae. Acta Otolaryngol $97: 117 \sim 126,1984$.

15）浅野公子：小児を中心に急増する滲出性中耳炎. Medical Tribune 17: 4 5, 1984.

16）飯野ゆき子, 石戸谷淳一, 池田美智子, 他：滲 出性中耳炎の遷延化济影響を与兄る因子一特に 貯留液中の細菌との関係について一。 日耳鼻 92 : 1183 1191, 1989.

$\left(\begin{array}{l}\text { 原稿受付: 平成 } 2 \text { 年 } 8 \text { 月 } 23 \text { 日 } \\ \text { 原稿採択 : 平成 } 2 \text { 年 } 10 \text { 月 } 5 \text { 日 } \\ \text { 別刷請求先 : 小林一豊 } \\ \text { 个 } 060 \text { 札幌市中央区南 } 1 \text { 条西 } 16 \\ \text { 札幌医科大学耳鼻咽喉科学教室 }\end{array}\right)$

